\title{
OTR3. MÉTODOS DE GENOTIPAGEM DOS SNPS FUNCIONAIS DO GENE FCGR2C.
}

Ana Claudia Dantas Machado; Guilherme Afonso Meloํㅜㄹ Claudio Gustavo Stefanoff ${ }^{1}$.

${ }^{1}$ Instituto Nacional de Câncer.

INTRODUÇÃO Variantes funcionais determinadas geneticamente vem sendo associadas com a eficiência dos mecanismos efetores Fc-dependentes mediados pelos anticorpos monoclonais das terapias antineoplásicas. Um polimorfismo de base única (SNP) no éxon 3 do gene FCGR2C, denominado "variante clássica" (c.169C>T, rs10917661), determina a expressão funcional do FcүRIIc (ORF/STOP) em células NK humanas, ao passo que outras duas variantes no íntron 7, descritas como "variantes não clássicas” (897+1 A>G, rs76277413 e 898-1 C>G, rs430178), ocasionam códons de parada em aproximadamente $20 \%$ dos portadores de genótipo FCGR2CORF. Uma característica notável do FCGR2C é a sua homologia com os genes FCGR2A e FCGR2B que dificulta as abordagens metodológicas.

OBJETIVO O presente estudo teve como objetivo desenvolver e validar metodologias confiáveis para a análise das variantes polimórficas clássicas e não clássicas do gene FCGR2C, no intuito de subsidiar a investigação futura destes SNPs como biomarcadores de resposta clínica individual ao tratamento com anticorpos monoclonais.

METODOLOGIA Foram utilizadas amostras de RNA e DNA genômico obtidas de doadores voluntários $(\mathrm{n}=26)$ e de linhagens celulares. Para a análise do SNP clássico, foram adotadas duas estratégias de PCR em ninho (nested) com o objetivo de amplificar especificamente o FCGR2C numa primeira etapa; uma das estratégias baseou-se na amplificação a partir de cDNA (fragmento $810 \mathrm{pb}$ ) e outra a partir de DNA genômico (fragmento $6.250 \mathrm{pb}$ ). Em ambos os casos, uma segunda etapa de PCR foi utilizada para a amplificação dos fragmentos contendo o SNP rs10917661, que posteriormente foram purificados e sequenciados. Para a análise das variantes polimórficas não clássicas, localizadas nas regiões 5' (rs76277413) e 3' (rs430178) do intron 7 (regiões altamente homologas ao gene FCGR2A), foi utilizada uma estratégia de amplificação touchdown a partir de DNA genómico, seguido de sequenciamento direto. 
RESULTADOS A análise do SNP clássico, de acordo com a estratégia de genotipagem de cDNA, revelou 6/26 doadores (23,07\%) com genótipo ORF / ORF; 18 / 26 doadores $(69,23 \%)$ com genótipo STOP / STOP e $2 / 26$ doadores (7,7\%) com genótipo heterozigotos ORF / STOP. Quanto às variantes não clássicas, para o trecho do SNP rs76277413 $(897+1 \mathrm{~A}>\mathrm{G})$ três dos cinco iniciadores forward desenhados permitiram amplificar o gene FCGR2C com sucesso; os amplicões sequenciados exibiram um nucleotídeo T na posição $897+28$ e a sequência CT na posição 897+61. Para a região do SNP rs430178 (898-1C>G) os três iniciadores "forward" testados permitiram obter produtos específicos que exibiram um nucleotídeo C na posição 939, indicando especificidade dos métodos de PCR.

CONCLUSÃO Durante o presente trabalho, padronizamos com sucesso métodos de PCR para a análise das variantes polimórficas clássicas e não clássicas do gene FCGR2C. Os nossos resultados preliminares alertam sobre a necessidade de uma correta padronização e validação dos métodos de genotipagem dos SNPs funcionais nos genes dos Fc $\gamma$ Rs, particularmente no gene FCGR2C que apresenta mais de 96\% de homologia com os genes FCGR2A e FCGR2B.

PALAVRAS-CHAVE SNP, FCGR2C, variantes polimórficas. 